\title{
CICLO DE GREVES NA AGROINDÚSTRIA AÇUCAREIRA: Pernambuco, 1964 a 1968
}

\author{
Mauro Guilherme Pinheiro Koury*
}

\begin{abstract}
Este artigo faz uma revisão das greves rurais no setor da agroindústria açucareira da Zona da Mata Pernambuco, Brasil, no período pós-golpe militar de 1964 a 1968, com base em material documental, especialmente da fonte jornalística da época. Observando a composição do bloco no poder e as alianças estabelecidas entre setores políticos conservadores e o clero, o artigo explora a ambigüidade do papel dos sindicatos rurais da região, à época, que oscila entre um órgão de colaboração com o Estado autoritário e de representação dos interesses de classe dos trabalhadores rurais da região no pós-64.

PALAVRAS-CHAVE: greves rurais, autoritarismo, reestruturação do movimento sindical rural.
\end{abstract}

Este artigo tem a intenção de passar em revista as greves rurais na agroindústria açucareira de Pernambuco, no período compreendido entre os anos de 1964 a 1968, e levantar algumas questões sobre o processo de reestruturação do movimento sindical rural pós 1964.

A repressão advinda com o golpe militar de abril de 1964 esfacela os movimentos sociais e políticos no campo e na cidade brasileiros. No Nordeste e em Pernambuco, em particular, a repressão recai de uma maneira particularmente forte no campo, sobre dois movimentos sociais significativos: as Ligas Camponesas e os sindicatos rurais. Tais movimentos são desarticulados, com as Ligas Camponesas postas na ilegalidade e subsequentemente destruídas, e os sindicatos, embora poupados como instituição, repensados e repostos a funcionamento sob um rígido controle estatal.

A razão de o Estado autoritário em implan-

\footnotetext{
* Professor do Departamento de Ciências Sociais da Universidade Federal da Paraíba. Doutorando do Programa de Pós-Graduação em Sociologia da Universidade Federal de São Carlos (UFSCar). Coordenador do GREM. Campus I - Bloco V - Cidade Universitária. Cep: 58.051970 - João Pessoa - PB - Brasil. maurokoury@gmail.com
}

tação poupar a instituição sindical provinha do fato de a estrutura sindical brasileira já conter, em sua legislação, as formas de sua submissão ao controle, fiscalização e condicionamento estatal, não precisando mais do que ajustes para tornar a legislação sindical brasileira em uma das mais arbitrárias do mundo contemporâneo.

A legislação sindical tornou-se, assim, mais um aparelho de coerção dos trabalhadores pelo Estado, e os sindicatos, veículos manipuláveis para uma possível legitimação passiva do Estado autoritário, tanto quanto agenciadores da economia política do Estado junto aos trabalhadores. Aos sindicatos estaria destinado um papel de agente mediador entre Estado e trabalhadores.

A ação de mediação foi a principal função destinada aos sindicatos pelo Estado autoritário em implantação no país e exercitada através dos mecanismos de persuasão, coerção e manipulação das reivindicações e lutas dos trabalhadores. Aos sindicatos caberia, então, a busca de manutenção da ordem nas bases, caso houvesse uma articulação de interesses e reivindicações dos seus membros, pelo desestímulo a seguirem em frente, ou 
pela integração das reivindicações à máquina burocrática da Justiça do Trabalho, ou de órgãos diversos, como, na época, o IBRA (Instituto Brasileiro de Reforma Agrária) e outros. Isso os faria agir no sentido de esvaziamento de possíveis pressões coletivas à expansão e reorganização do capital, encobrindo sua função como órgão de representação dos trabalhadores.

Em troca dessa mediação, o Estado autoritário se comprometia junto à instituição sindical a concretizar programas de ação de cunho assistencial destinados aos trabalhadores. O Estado buscava assumir certas bandeiras de luta, através do controle da instituição sindical e pela ação de mediação a ela conferida nessa troca. Eram bandeiras caras ao processo de organização e lutas dos trabalhadores até então, como força política, tais como a da Reforma Agrária e a luta pela cidadania e garantia dos direitos trabalhistas e sociais. Ao assumi-las e transformá-las, o Estado as remetia aos trabalhadores de forma paternalística, via sindicatos, o que ajudava a amainar as tensões sociais. A rede sindical servia, pois, como uma espécie de agente apaziguador de tensões e um veio de ação estatal, vendendo uma imagem de paz social como financiadora do progresso e do bem estar social e como sinônimo da colaboração entre classes através do Estado.

\section{O MOVIMENTO SINDICAL RURAL COMO COLABORADOR DO ESTADO E REPRESEN- TANTE DE CLASSE}

OEstado autoritário em implantação no país, ao comprometer-se com os movimentos sindicais em seu todo - e, aqui, especificamente, o rural e sua base-, conclamando-os a participar na formulação de reformas sociais, ${ }^{1}$ entre elas a reforma agrária, estabelece a linha possível de contradição entre o movimento sindical, sua base e o Estado autoritário em Pernambuco, no período de 1964 a

Ver, por exemplo, o discurso do Marechal Castelo Branco no Ministério da Fazenda, em 13 de novembro de 1965 (Castelo Branco, 1966, p.264).
1968: de um lado, o movimento sindical rural aparece como colaborador e agente do Estado autoritário junto às suas bases; de outro, ele deve atender à pressão desse mesmo movimento para execução dos compromissos de reformas sociais por ele assumidos.

No sindicalismo rural de Pernambuco e, especificamente, da Zona da Mata pernambucana, essa contradição se explica, de um lado, a partir do envolvimento do clero católico conservador com o movimento sindical rural nos anos de 1960 a 1964, anteriores ao golpe militar; e de outro, pela participação dessa mesma ala conservadora do clero no conjunto de forças que patrocinaram o golpe e tentavam minar o frágil alicerce constitucional brasileiro de então.

Patrocinado e custeado pela CLUSA (Cooperative League of the United States of America), pela USAID (United States Agency for International Development), através da Aliança pelo Progresso, pelo IBAD (Instituto Brasileiro de Ação Democrática) o IPES (Instituto de Pesquisas e Estudos Sociais) e outros, o clero conservador pôde desenvolver um movimento de reação às Ligas Camponesas e ao movimento sindical rural de esquerda que se iniciava e se encontrava em pleno desenvolvimento no estado de Pernambuco e no Nordeste. Ele foi abastecido de estudos, assistência técnica e política, no intuito de possibilitar um projeto e uma plataforma política coerente e contrária à dos movimentos presentes. Tratava-se de uma alternativa possível, a ser ganha e executada através da formulação de uma proposta política de reforma agrária contrária a proposição de uma reforma agrária na lei ou na marra das Ligas Camponesas e de uma proposta democrata-cristã das relações entre trabalhadores e patronato através da legislação trabalhista e dos direitos.

Os estudos sobre a questão agrária do IBADIPES, ${ }^{2}$ a assistência técnica e monetária da CLUSA e da USAID (Aliança para o Progresso) em cooperativismo e sindicalismo rural foram refor-

Ver, principalmente, os estudos do IBAD (1961) e do IPES (1964) sobre a reforma agrária. 
ços significativos à expansão do movimento sindical rural católico e de sua plataforma política em Pernambuco e no Nordeste.

O principal eixo de de base toda a construção política da plataforma sindical do clero conservador assentava-se na ideia de colaboração entre classes, baseada em garantias básicas junto ao patronato e junto ao Estado no sentido de cumprimento e legalização dos direitos do trabalhador rural. Essa ideia de direitos permearia, após o golpe militar, toda a estratégia organizativa da estrutura sindical rural em Pernambuco, seja no apoio ao golpe, seja no processo de cisão e cobranças do sindicalismo e do clero conservador ao Estado e ao patronato pelo não cumprimento do conjunto de garantias básicas motivadoras da aliança e do compromisso do clero conservador e do sindicalismo rural com o Estado autoritário em implantação no país (Sigaud, 1979; Koury, 1983; Rosa, 2006).

A aprovação do Estatuto do Trabalhador Rural, em março de 1963, foi vista como um grande passo no processo de cidadania rural e na garantia dos direitos trabalhistas do trabalhador por parte do Estado. Restava conformar e pressionar o patronato rural, através da lei, para que ele cumprisse a exigência da lei e efetivasse a cidadania e os direitos do trabalho.

O patronato, principalmente aquele ligado à agroindústria açucareira, era visto pelo clero conservador como um problema, talvez o principal, para a garantia dos compromissos da aliança entre sindicalismo e Estado. Os atritos com o patronato antes e, sobretudo, após abril de 1964, durante os primeiros anos do golpe, seriam avaliados pelo clero conservador, em depoimentos e relatórios, ${ }^{3}$ como a causa principal da perda de confiança dos trabalhadores no papel do sindicato e nas possibi-

\footnotetext{
${ }^{3}$ Ver relatórios da SORPE (Serviço de Orientação Rural de Pernambuco) entre abril de 1964 e dezembro de 1969 constantes do arquivo guardado na Regional Nordeste II da CNBB (Conferência Nacional dos Bispos do Brasil). Ver, também, depoimento do Padre Paulo Crespo ao Jornal do Comércio de 21 de maio de 1964 e no Diário de Pernambuco de 14 de setembro de 1965 sobre as relações entre sindicalismo rural, trabalhadores e patronato na Zona da Mata pernambucana, entre outros tantos.
}

lidades de aliança com a legislação trabalhista e com o Estado autoritário em seu conjunto.

O patronato era acusado de possuir uma mentalidade retrógada que o cegava ou tornava turva a sua visão sobre a importância, a médio e longo prazo, da ação sindical e do cumprimento da legislação trabalhista constante nos Estatutos do Trabalhador Rural. Na avaliação do clero, ${ }^{4} \mathrm{o}$ patronato

... acostumado a ser dono dos seus trabalhadores e de suas famílias, dentro dos tradicionais e velhos laços do latifúndio, não conseguia enxergar em longo prazo e boicotava a organização sindical dos trabalhadores rurais e o trabalho dos sindicatos de pressão e garantia dos direitos para as suas bases. Aos olhos dos latifundiários, qualquer tentativa de organização e mobilização dos trabalhadores era sentida como uma ameaça concreta que deveria ser cortada pela raiz. Partisse de onde partisse. (Sorpe, 1965)

O que significava dizer, de acordo com o depoimento do Padre Paulo Crespo, citado por Tamer (1968, p.135-136), que os sindicatos rurais democrata-cristãos se encontravam de mãos amarradas e tenderiam a perder terreno para qualquer outra tendência que por acaso houvesse no movimento. Padre Crespo estava se referindo ao crescimento das esquerdas nos movimentos sociais rurais durante o governo de Miguel Arraes de Alencar, nos primeiros anos da década de 1960, e ao modo como o clero católico conservador estreitou laços com setores que tramavam o golpe militar. Referia-se, também, aos acordos construídos na aliança e as dificuldades com o patronato pernambucano, principalmente na Zona da Mata açucareira. Dificuldades que só pioraram com o advento do golpe de 1964 pela violência do patronato nas relações com os sindicatos e a truculência em relação à ação pelos direitos dos trabalhadores.

${ }^{4}$ Ver o documento elaborado pela equipe do SORPE em 1965 , constante do arquivo guardado na Regional Nordeste II da CNBB: "Sindicalismo rural e a Revolução de 31 de março: dificuldades impostas pelas mentalidades retrógadas dos empregadores e latifundiários em Pernambuco". 


\section{ÁREAS DE ATRITOS E TENSÃO}

O significado de uma contraproposta àquela de reforma agrária das Ligas Camponesas não se reduzia unicamente à vontade de esvaziar politicamente o movimento, mas à procura de modernizar e dinamizar a estrutura agrária brasileira e nordestina, a pernambucana em particular. Em sua proposta de modernização agrária, encontrava-se como uma das demandas urgentes a quebra dos redutos de conservadorismo e das barreiras à mudança cultural dos latifúndios (IBAD, 1961, p.181).

Com o advento do golpe militar, essa seria uma das áreas de atrito com o Estado autoritário em implantação, principalmente por força das dificuldades de implantar as reformas necessárias à modernização das relações no campo, pelo peso da aliança do Estado com os chamados latifundiários, que impunha limites ao avanço da questão agrária no país e, especificamente, em Pernambuco. Para o clero conservador, juntamente com setores remanescentes do IBAD-IPES que pensavam a questão agrária, a reformulação da estrutura agrária no país era uma necessidade e um fundamento do processo de modernização. É importante lembrar aqui que, durante os primeiros anos da década de sessenta, principalmente a partir de 1961, o IBAD e o IPES compuseram um programa de modernização do campo e de reforma agrária que deveria ser implantado e executado logo após a derrubada do regime constitucional do país. ${ }^{5}$

Cabe salientar, contudo, que a modernização da estrutura agrária era uma das principais metas desses setores de direita envolvidos com a questão agrária no país, em primeiro lugar, como forma de contenção das áreas de tensão social no campo no Brasil e, principalmente, no Nordeste, onde os movimentos sociais ganharam forte expressão política. Em segundo lugar, como forma de submeter o bloco agrário no processo hierárquico de composição do poder político do Estado, possibilitando a consolidação da burguesia indus-

Não está prevista, nos limites deste artigo, uma discussão do conteúdo da modernização do campo e da reforma agrárias dos projetos apresentados pela direita. trial associada como bloco hegemônico ao processo de dinamização e modernização agrária.

Os setores de direita de origem Ibad-Ipesiana envolvidos com a questão agrária no país, logo após o golpe militar, se organizaram como grupos de pressão junto ao governo federal para levar à prática, por meio de providências concretas e o mais rapidamente possível, o programa de reformulação da estrutura agrária por eles proposto. Junto a esses setores estava o clero católico conservador: a $\mathrm{CNBB}$, no plano nacional, e os setores ligados ao movimento sindical rural no Nordeste e, sobretudo, em Pernambuco. Como grupos de pressão, conseguem, logo nos primeiros meses do golpe, o encaminhamento do projeto de lei do Estatuto da Terra, aprovado pelo congresso nacional, e transformado na Lei de n. 4.504, de 30 de novembro de $1964 .^{6}$

O Estatuto da Terra iria encontrar forte reação do lado mais conservador do bloco agrário, também participante da aliança que tornou possível o golpe militar. Essa reação conseguiu criar uma barreira eficaz à implantação do conteúdo da lei e de todo e qualquer programa de reforma da estrutura agrária, mostrando o poder de influência, junto ao Estado autoritário em implantação, do setor mais conservador do bloco agrário no país, os então chamados de latifundiários. Isso levou à abertura de um leque de questionamentos dos setores de direita de origem Ibad-Ipesiana e da igreja católica envolvidos com a questão agrária e a modernização do campo, causadoras de tensões e, em alguns momentos, de conflitos com o Estado autoritário.

Essas tensões e conflitos no interior da base aliada criaram arestas de descontentamento, o que levou o Estado a ampliar a rede sistêmica de coerção e controle sobre ela e, por conseguinte, sobre toda a sociedade nacional. Essa ampliação das redes de coerção e controle tinha como meta a diminuição das pressões dos grupos aliados sem, contudo, se desfazer do apoio político deles. Segundo José Gomes da Silva, um dos representantes do pensamento Ibad-Ipesiano envolvido com a

${ }^{6}$ Essa lei dispõe sobre o Estatuto da Terra, englobando a reforma agrária e a política para o desenvolvimento rural. 
questão agrária, em seu depoimento em forma de livro (Silva, 1971), o Estado autoritário em implantação no Brasil, após esses primeiros atritos da base aliada, procurou manter a coalizão e o apoio dos dois grandes blocos, heterogêneos em seu conjunto: $\mathrm{o}$ agrário e $\mathrm{o}$ industrial. Ao mesmo tempo, procurava uma maior abertura ao capital multinacional e a ampliação do seu poder de influência na economia nacional. Nesse jogo, procurava, sob sua mediação, subordinar o bloco agrário e o industrial ao capital internacional e promover as mudanças necessárias à modernização capitalista no país.

Ainda seguindo essa linha de pensamento, embora de um ponto de vista de esquerda, Jacob Gorender, em entrevista ao autor, afirmava que "a debilidade da burguesia nacional, mesmo associada, conclamava mais uma vez a intervenção estatal para promoção do crescimento e desenvolvimento do capital no país, via autoritarismo". Essa debilidade fortalecia o papel do Estado e sua autonomia relativa frente aos blocos agrário e industrial. Ao mesmo tempo, garantia novas formas de acumulação, sob controle do capital multinacional e servia para neutralizar as possíveis áreas de atrito e tensão no interior dos grupos em aliança que pudessem comprometer o equilíbrio interno e o desenvolvimento de novas formas de capital surgidas no processo de desenvolvimento do capitalismo internacional em seu todo.

O Estatuto da Terra, nesse jogo de acomodações internas dos grupos no poder, seria paulatinamente esvaziado do seu poder de lei para a modernização agrária, com redefinição do conceito de reforma agrária presente no seu interior. Esses processos de esvaziamento e redefinição, por sua vez, seriam realizados de forma paulatina através da dinâmica interna dos conflitos entre os grupos no poder, de sua acomodação e da possibilidade de ampliação da modernidade agrária e do controle do trabalho no campo sob a égide do capital multinacional.

Esse jogo de acomodações dos grupos no poder e o crescente esvaziamento e redefinições na Lei $\mathrm{n}^{\circ} 4.504$, que deu origem ao Estatuto da Terra - associado ao desrespeito crescente dos seto- res mais conservadores do patronato rural aos direitos trabalhistas no campo, principalmente na agroindústria açucareira em Pernambuco - causaria, entre os anos de 1964 e 1969, ranhuras no clero conservador nacional e pernambucano, em particular. Assim, o Estado autoritário abria um campo de possibilidades de atritos e questionamentos na relação entre o sindicalismo rural e a política econômica e social do governo.

Tais atritos, questionamentos e ranhuras não significavam uma cisão entre o clero conservador, os setores de direita envolvidos com a questão agrária e o movimento sindical rural com o Estado, mas estranhamentos e cobranças dos compromissos de reformas assumidas pelo Estado e não executadas. No interior do movimento sindical, esses questionamentos consistiam em atitudes de representação de classe, a partir das reivindicações da base, frente aos desmandos crescentes do patronato e da burocracia estatal.

Em Pernambuco, desde os momentos iniciais do processo de reestruturação do sindicalismo rural pelas forças conservadoras do clero católico, o movimento sindical enfrentou o patronato mais conservador - por ele denominado de latifundiários -, sofrendo perseguições que visavam a aniquilar e extinguir toda e qualquer presença organizada dos trabalhadores no campo. Com o golpe de 1964, o clero conservador foi indicado como tutor do movimento sindical rural em Pernambuco. No primeiro ano, esse processo de tutela buscou amainar a opressão e a repressão patronal dirigidas aos trabalhadores e, sobretudo, àqueles ligados ao movimento sindical, além de pressionar o governo autoritário para a implantação das reformas sociais no campo.

Vários fatores fragilizavam ainda mais a estrutura sindical e afastavam os trabalhadores do movimento: a intransigência do patronato mais conservador, que não permitia a mediação sindical nas questões do trabalho rural, não respeitando a legislação constante no Estatuto do Trabalhador Rural; a repressão violenta a qualquer mobilização dos trabalhadores; a perseguição às lideranças sindicais a partir da base; e o clima de 
insegurança vivido pelos sindicatos e sindicalistas, sob constantes ameaças de invasão de sedes e espancamento e assassinato de dirigentes.

Por outrolado, a crise periódica da agroindústria açucareira em Pernambuco, que buscava novos investimentos do Estado a fundo perdido, complicava ainda mais a vida dos trabalhadores rurais das usinas e engenhos da região, por força do atraso dos salários por meses a fio, associado ao impedimento do plantio de lavoura de subsistência e a uma política de expulsão dos trabalhadores permanentes, chamados moradores, ${ }^{7}$ das terras onde viviam há décadas.

Esses fatores, em conjunto, dificultavam as relações de trabalho no campo, ao mesmo tempo em que também complicavam as relações entre os sindicatos e seus tutores, bem como as relações entre os trabalhadores e a estrutura sindical. Essas complicações, por seu turno, faziam com que a estrutura sindical rural vivesse uma ambivalência e uma ambiguidade nas suas ações e atitudes: de um lado, os sindicatos amedrontavam-se e buscavam desestimular ações reivindicativas de suas bases; de outro lado, procuravam meios de comprometer o Estado na execução dos compromissos assumidos, relativos às reformas sociais no campo. $^{8}$

Sem força política e poder de representação de classe, restava aos sindicatos sobreviverem à sombra dessa ambiguidade e ambivalência, o que aumentava o distanciamento dos trabalhadores, sujeitos aos desmandos do patronato. Aos sindicatos e à estrutura sindical restava apenas a utilização de mecanismos de apaziguamento e de controle de tensões dos trabalhadores, sob a promessa de resolução das demandas encaminhadas via

${ }^{7}$ Os trabalhadores permanentes estavam presos por laços de moradia nas terras dos engenhos e usinas, onde cultivavam lavoura de subsistência como complemento salarial e pagavam com uma parte dos produtos cultivados o foro ou a permissão de moradia.

${ }^{8}$ Por outro lado, essa ambiguidade se ampliava, na medida em que a luta pela aplicação do Estatuto da Terra e do Estatuto do Trabalhador Rural significava, também, a transformação paulatina da mão de obra permanente em temporária (em Pernambuco chamada de clandestina), e a expulsão dos trabalhadores permanentes para a periferia das cidades, onde surgem bairros inteiros de trabalhadores desempregados ou subempregados da agroindústria açucareira.
Estado, respondendo a pressões de modernização agrária dos setores de direita comprometidos com a questão agrária, entre eles o clero conservador.

Como órgãos de mediação entre trabalhadores rurais e o Estado autoritário, os sindicatos rurais vivenciavam uma contradição não resolvida: a de serem, em tese, órgãos de representação de uma classe, a dos trabalhadores rurais, e, ao mesmo tempo, na prática, funcionar como órgãos de controle das aspirações dessa mesma classe. Essa contradição se acentua quando os compromissos assumidos pelo Estado tendiam a ser desrespeitados e engavetados, o que se tornava fonte de tensão e pressão para o cumprimento da legislação.

Exemplos dessas contradições vividas pela estrutura sindical no campo são várias, como, por exemplo, as pressões para o cumprimento do Estatuto da Terra, ou pela execução da lei dos dois hectares, cara ao clero conservador pernambucano, via o SORPE, do sindicalismo rural de Pernambuco, durante os anos de 1964 a 1968; ou as reivindicações trabalhistas, nesse mesmo período, as quais, de uma forma ou de outra, chegavam aos sindicatos rurais mediadas através da burocracia jurídica. Um caso exemplar pode ser visualizado na atuação do sindicato dos trabalhadores rurais do município do Cabo, na mata sul pernambucana, que trouxe para si as reivindicações trabalhistas e sociais vindas da base e construiu movimentos de greve, cuja face potencialmente política seria manifestada na greve geral dos trabalhadores do Cabo no ano de 1968.

Relatar e analisar esses movimentos de greve na mata sul pernambucana, entre os anos de 1965 a 1968, é o objetivo central deste artigo.

\section{OS MOVIMENTOS DE GREVE NA MATA PERNAMBUCANA}

Discutir os focos de reivindicações e os movimentos de greve surgidos na mata sul de Pernambuco no período de 1964 a 1968 remete necessariamente à análise e à discussão da contradição entre ser órgão de colaboração com o Estado 
e de representação de classe, vivida pela instituição sindical no pós-1964. O momento do golpe se faz importante para a compreensão do panorama em que se debatia o sindicalismo rural no Brasil e em Pernambuco, após a instauração do estado autoritário no país. Embora a legislação sindical brasileira seja arbitrária desde a sua origem no Estado Novo, o sindicalismo rural originou-se e teve sua expansão em um momento da história política do país em que vozes, invisíveis até então, clamaram um lugar ao sol, e a questão agrária tornou-se uma luta pela ampliação da cidadania ao homem do campo. Os movimentos sociais no campo, entre eles o sindical, tornaram-se uma força política significativa, autodenominada de movimento camponês, numa luta por reformas sociais que dessem às famílias camponesas melhores condições de vida e trabalho. Desse modo, o sindicalismo rural e as Ligas Camponesas eram canais de expressão e organização em busca da ampliação da cidadania e da visibilidade política do homem do campo.

Com o advento do golpe militar de 64 , a perseguição política e a repressão violenta dele advinda - prisões, assassinatos, ameaças, e a cultura do medo assentada no país, e no campo em particular-trouxeram como consequência a pulverização dos sonhos e das lutas camponesas. As Ligas foram colocadas na clandestinidade e exterminadas aos poucos, e a experiência sindical dos trabalhadores rurais foi mantida, embora redefinida: a estrutura sindical rural passou à tutela do Estado, sob a coordenação do clero conservador, que assumiu um papel de mediador entre o Estado autoritário em implantação no país e os trabalhadores rurais. Tornou-se, desse modo, um veículo de legitimação das ações governamentais e um órgão primordialmente apaziguador de tensões e de colaboração com o Estado, o que, em um primeiro momento, se adequaria aos planos iniciais do clero conservador, centrados na pacificação das tensões sociais nas relações entre capital e trabalho no campo, e no conceito cristão de colaboração entre classes como fundamento da paz e da harmonia sociais.

Em Pernambuco, principalmente na Zona da Mata pernambucana, as funções de colaboração e de apaziguamento de tensões irão medrar na maior parte das ações sindicais no campo, no período aqui estudado. Quando existiam pressões dos trabalhadores para uma ação de defesa das reivindicações e dos direitos trabalhistas e de permanência na terra, como morador, isto é, como trabalhador permanente, a função de colaboração e de órgão apaziguador de tensões se tornava mais visível, evidenciando, no limite, a contradição vivenciada pela estrutura sindical rural. Diante da inexistência de uma saída ou de soluções do Estado para situações críticas, que provocavam a mobilização (ou o clamor) dos trabalhadores, a entidade sindical busca a desmobilização, ou mesmo pressiona o Estado para apresentar alternativas capazes de acalmar os ânimos, considerandose sem forças para a contenção das bases.

Em 1965, uma grande crise na agroindústria do açúcar, na mata sul de Pernambuco, leva a maior parte de seus municípios a decretarem situação de calamidade pública. Com vários meses de atraso no pagamento de seus salários, os trabalhadores rurais ameaçavam invadir as cidades em busca de comida. Havia também uma crise no comércio local, pela não circulação dos salários nos armazéns e lojas. Hordas de desvalidos perambulavam pelos municípios da região, movidas pela fome e pela ampliação do desemprego rural. Com a desculpa da crise da agroindústria, o patronato pressionava o governo por novas verbas a fundo perdido, ao mesmo tempo em que, usando o mesmo argumento da crise, expulsava grande contingente de moradores dos seus engenhos e usinas.

Os sindicatos rurais da região, pressionados pelos acontecimentos, solicitaram apoio da FETAPE (Federação dos Trabalhadores na Agricultura de Pernambuco). A FETAPE, por sua vez, através de um memorial escrito sob a supervisão do SORPE e enviado ao Presidente Castelo Branco", ${ }^{9}$ alertava-o sobre a gravidade da crise e solicitava ajuda para contornar "o mais rapidamente possível a situação em que se encontravam os tra${ }_{9}^{9}$ Diário de Pernambuco, Recife, 15 nov. 1965. 
balhadores" rurais dos municípios atingidos, "sob o perigo de ser decretada uma greve geral na agroindústria açucareira do Estado".

Alertava ainda que os sindicatos e a Federação não tinham mais meios de controlar os trabalhadores, e que o perigo de paralisação iminente teria um caráter espontâneo e independente de qualquer interferência sindical. E concluía o memorial com os seguintes termos:

Como compreendemos que uma greve geral paralisaria toda a atividade açucareira com graves reflexos na economia nacional, solicitamos aos nossos companheiros sindicalistas que implorassem junto às suas bases para dar um crédito de confiança a V. Exa. e ao seu governo, pois, sabedor destas tristes ocorrências V. Exa. tomaria imediatas providências no sentido de resolver o impasse. (Diário de Pernambuco, 1965)

Ao denunciar as arbitrariedades vividas pelos trabalhadores rurais da mata pernambucana e pressionar o Estado para uma solução, a FETAPE e os sindicatos rurais envolvidos na crise parecem manter o compromisso com os trabalhadores e assumir o seu papel de órgão de classe, representando suas bases. Mas, de forma concomitante, essa ação de denúncia e pressão institucional, através de um memorial, evidencia o papel que lhe foi atribuído pelo Estado autoritário, de órgão apaziguador de tensões: invitar as bases para um voto de confiança ao governo federal, na tentativa de desmobilização de uma possível greve geral, movida pela fome e desespero dos trabalhadores.

A pressão e a cobrança de uma solução do governo federal torna-se nada mais do que uma satisfação pela impossibilidade de a estrutura sindical evitar uma possível greve geral espontânea dos trabalhadores famélicos. Havia, pois, a necessidade de uma ajuda do Estado para solucionar a crise periódica que se abateu sobre a agroindústria e ampliou o grau de desespero e desamparo dos trabalhadores nela envolvidos.

Não se quer supor, aqui, que os sindicatos rurais e a FETAPE não estivessem sensibilizados com a situação dos trabalhadores na crise econômica da agroindústria do açúcar na Zona da Mata pernambucana. Mas é importante demonstrar as mãos amarradas do sindicalismo e o seu compromisso com o Estado autoritário, que se situa acima das questões da classe que representava. O papel de mediação entre os trabalhadores e o Estado tornava visíveis essas mãos amarradas e mostravam - ou pareciam mostrar - a duplicidade de papéis em que se debatia o movimento sindical rural em Pernambuco. Era um órgão de classe, quando utilizava a sua função de representação para alertar o governo da grave crise e solicitar sua intervenção, e exercia o seu papel de colaboração, ao afirmar a sua impossibilidade de desmobilizar uma possível greve geral na mata sul do estado, solicitando uma ação urgente para a resolução da crise, mesmo que momentânea. A função de representação de classe estava sendo subsumida pela função de colaboração com o Estado no controle dos trabalhadores.

Nesse duplo jogo entre representação e colaboração, o sindicalismo rural em Pernambuco procurava sobreviver, no interior de uma política de apoio ao Estado autoritário em implantação, movida pelo clero conservador que o tutelava e uma situação de crise permanente de que se aproveitava o patronato para protelar dívidas trabalhistas e expulsar contingentes de trabalhadores permanentes de suas terras, aumentando a miséria e o desamparo dos trabalhadores. Esse fato refletia, em outras palavras, o próprio refluxo político do movimento camponês ${ }^{10}$ como força política, sem condições de impor uma representação consistente do aparelho sindical, pela cultura do medo instalada frente à repressão advinda do recente golpe.

Os canais de representação permitidos pelo Estado autoritário ao sindicalismo rural eram os da mediação, do apaziguamento e da colaboração. O medo de represálias por parte do patronato e do Estado autoritário e a própria ideologia confusa dos dirigentes sindicais que assumiram os sindicatos como interventores ou indicados pelo clero conservador após o golpe os impedia de estimular

${ }^{10}$ Usa-se, aqui, o termo movimento camponês como um conceito aplicado pelos próprios trabalhadores rurais em Pernambuco, para definir os movimentos sociais rurais, inclusive o sindical, englobando desde trabalhadores rurais permanentes e temporários até categorias de foreiros, meeiros e pequenos proprietários rurais. 
ou mobilizar os trabalhadores rurais para uma greve espontânea. A Lei de Greve, como o Decreto-Lei $\operatorname{de~}^{\circ} 4.330$ de $1^{\circ}$ de junho de 1964 ficou conhecido, por outro lado, serve aqui como um exemplo dessa função e da limitação do sindicalismo rural no pós-golpe.

Com o processo lento e burocrático a percorrer, estipulado pela Lei de Greve, mesmo que os sindicatos rurais procurassem encampar, de forma legal, as reivindicações dos trabalhadores e o movimento paredista delas decorrente, encontraria um efeito contrário ao desejado. Primeiramente porque, com os prazos exigidos pela Lei de Greve, conduzir até a uma possível greve era uma missão burocraticamente longa, que quase saía das mãos dos sindicatos e dos trabalhadores para as mãos do Ministério do Trabalho, através das Delegacias Regionais e Tribunais Regionais do Trabalho. Em segundo lugar, o movimento tendia a se isolar por unidade de produção (usina $x$, engenho $y$ ), o que fragmentava e dificultava uma organização paredista geral, funcionando como limitante de um processo de questionamento mais amplo, isolando cada unidade de produção, ou mesmo cada indivíduo, em suas reivindicações específicas, no contexto próprio da burocracia em que o sindicato se via envolvido juridicamente. ${ }^{11}$ As delegacias e tribunais regionais do trabalho assumem, assim, de uma forma indireta, a liderança do movimento, tornando-se porta-vozes de um processo de conciliação entre os trabalhadores e o patronato, e a luta pelos direitos passa a ser vista como burocrática e desmobilizante.

Esse problema pode ser sentido nos movimentos paredistas surgidos na mata pernambucana entre 1966 a 1968, aos quais a FETAPE era contrária, nesse momento, por medo da repressão do patronato e do Estado autoritário a qualquer tipo de manifestação e mobilização camponesa. Quando solicitada a ajudar em um processo de mobilização, colocou-se como um agente desmobilizador e procurou encaminhar as reivindicações para o setor jurídico. Muitas vezes, essa

${ }^{11}$ Alguns exemplos podem ser vistos em Koury (1976). entidade comunicava às autoridades locais - governador, prefeitos, comandos militares e até o governo federal - qualquer possibilidade de insatisfação coletiva dos trabalhadores, e alertava os sindicatos sob seu comando a respeito do perigo de caminhar para uma greve, e dos cuidados que deveriam ter com agentes externos ao movimento. ${ }^{12}$

Em novembro de 1966, o sindicato dos trabalhadores rurais do Cabo marcou uma assembleia geral e, contrariando a FETAPE, decidiu encampar as reivindicações dos trabalhadores sob sua jurisdição e encaminhar um processo de greve, contrariando o pároco local, o Padre Antonio Melo. ${ }^{13}$ Esse processo seguiu todos os requisitos da Lei de Greve. Como primeiro passo, anunciou-se nos grandes jornais do estado a data, hora e local da assembleia, nos prazos exigidos pela legislação. Após a realização da assembleia geral e da decisão pela greve, a direção do sindicato encaminhou ofícios notificando os empregadores e a Delegacia Regional do Trabalho sobre a decisão de greve na agroindústria canavieira do município. Essa primeira fase da Lei de Greve foi concluída e eram esperadas as decisões do delegado regional do trabalho junto ao Ministério do Trabalho ${ }^{14}$ sobre o caráter não político do movimento. Verificada a instrumentalidade do movimento, a Delegacia Regional do Trabalho marcou uma reunião conciliatória entre o patronato, os trabalhadores rurais e o

12 Neste período a federação enviou diversos ofícios às autoridades militares sobre a infiltração de estranhos nos sindicatos e nas unidades de produção da mata pernambucana, e outros tantos alertando os sindicatos rurais da região sobre o perigo desta influência. Muitos destes ofícios podem ser encontrados nas páginas dos dois principais jornais de Pernambuco, o Diário de Pernambuco e o Jornal do Comércio, entre os anos de 1965 a 1968.

${ }^{13}$ É bom lembrar que o sindicato rural do Cabo se situava na paróquia do município controlado pelo Padre Antonio Melo, um dos tutores do sindicalismo rural em Pernambuco após o golpe. O outro padre era o Paulo Crespo, coordenador do SORPE. Apesar de ambos pertencerem ao clero conservador, e a ambos estarem destinados a tutela sindical no campo pernambucano, havia uma rixa forte entre os dois, e este dissenso passava também a ser da estrutura sindical no estado. Esta rixa é lembrada em vários depoimentos de dirigentes e assessores sindicais e ex-presidentes da federação que colocam o Padre Antonio Melo mais a direita que o Paulo Crespo, acusando o primeiro de solicitar a intervenção e prisão de vários dirigentes sindicais de origem católica ligados ao SORPE.

${ }^{14}$ Então, Ministério do Trabalho e Previdência Social. 
sindicato para o dia 07 de dezembro de 1966, quatro dias antes do estipulado para o início do movimento. Esse último detalhe fez adiar por mais um dia o início do movimento, conforme a Lei de Gre$v e$, que define a necessidade de cinco dias úteis, entre a primeira reunião de conciliação e o dia marcado para a eclosão do movimento, para que a Delegacia do Trabalho encontre meios de promover a conciliação entre as partes e evite a deflagração da greve.

Passado o prazo legal exigido por lei, os trabalhadores rurais da agroindústria açucareira do município do Cabo entraram em greve no dia 13 de dezembro de 1966. Essa greve englobava os trabalhadores rurais de quatorze engenhos do município e se estendeu até o dia 30 de março de 1967, tendo como reivindicações o pagamento de salários e férias atrasados, a manutenção dos moradores e a conservação de seus roçados junto a suas casas, nas propriedades em que trabalhavam.

O Tribunal Regional do Trabalho julgou pela legalidade do movimento e pela justiça das reivindicações. Entretanto, arguiu sobre a impossibilidade de atender a um dissídio coletivo no município, decretando que cada unidade de produção deveria entrar com uma reclamação individual, a fim de receber os atrasados, e que, no caso da permanência de moradores e dos roçados, caberia uma ação individual de cada morador junto ao IBRA e às Delegacias de Trabalho. ${ }^{15}$ Alertou também o patronato contra possíveis represálias contra os trabalhadores. ${ }^{16}$

Os relatos das entrevistas realizadas pelo autor com militantes do movimento sindical e de

${ }^{15}$ Esse resumo do processo da greve foi obtido no levantamento das notícias diárias veiculadas em dois jornais
pernambucanos, o Diário de Pernambuco e o Jornal do Comércio, de novembro de 1966 a abril de 1967, nas atas do sindicato dos trabalhadores rurais do Cabo e da Delegacia Regional do Trabalho, bem como em entrevistas com sindicalistas e militantes de esquerda que acompanharam o processo na época.

${ }^{16}$ Durante o período em que os trabalhadores dos 14 engenhos do município do Cabo estiveram parados, o patronato, desrespeitando a justiça do trabalho e a lei de greve, iniciou a contratação ilegal de trabalhadores clandestinos trazidos da região Agreste do estado, e aproveitou para destruir lavouras de subsistência dos trabalhadores permanentes em greve, ameaçando-os de expulsão sumária das suas terras. partidos políticos presentes no Cabo à época, os ofícios e as notas emitidos pela Federação e pelo sindicato rural do Cabo, bem como as notícias dos jornais da época pesquisados e já citados são unânimes em afirmar o aumento das represálias do patronato logo após a greve. Tais represálias se tornaram visíveis no aumento da pressão para expulsão dos moradores dos engenhos e das usinas locais, bem como no uso de tratores para destruir as lavouras de subsistência dos trabalhadores.

A contratação de mão de obra clandestina também aumentou bastante logo após o período da greve. Uma breve análise nos processos da Justiça do Trabalho de Pernambuco permite constatar as queixas dos trabalhadores permanentes nos engenhos e usinas locais quanto ao aumento da pressão patronal. Há relatos sobre lavouras destruídas, avanço do plantio da cana até a porta das casas dos trabalhadores, ameaças veladas ou abertas de capangas $^{17} \mathrm{e}$, em muitos casos, derrubada das casas dos moradores. Em todos os casos, esses fatos demonstram a perda de força política do movimento sindical rural e as mãos amarradas do sindicalismo em Pernambuco.

Oaparente ganho político - de enfrentar uma legislação feita para impedir qualquer mobilização, como a da Lei de Greve, de ter a greve considerada legal pela justiça do trabalho e muitas das reivindicações aceitas - parecia se esvanecer na fragmentação do movimento por unidade de produção e por família, de um lado, e pela morosidade do julgamento das ações movidas pelos trabalhadores individualmente, ou por unidade de produção, por outro. Acrescente-se a tudo isso o aumento das pressões para expulsão da mão de obra permanente no campo, a contratação abusiva da mão de obra clandestina pelo patronato e o subsequente aumento do sofrimento social vivido cotidianamente pelos trabalhadores sujeitos a esse processo.

Na avaliação da FETAPE e do SORPE, a greve apenas serviu para aumentar a expulsão dos moradores e para beneficiar o patronato, que aproveitou a crise para solicitar mais subsídios a fun${ }^{7}$ Milícias privadas. 
do perdido ao governo federal, através do IAA (Instituto de Açúcar e do Álcool). Na avaliação do sindicato rural do Cabo e de alguns militantes de esquerda disponibilizados para o trabalho no campo, apesar das dificuldades de garantia dos itens ganhos na pauta de reivindicações, a mobilização dos trabalhadores de quatorze engenhos do município e o fato de conseguirem organizar uma greve considerada justa e legal pela justiça do trabalho já são fatos que permitem uma avaliação positiva do movimento.

A luta subsequente poderia ser vista como outra etapa da mobilização, caso fosse encampada e levada adiante pelo sindicato. Essa é a avaliação do presidente do sindicato rural do Cabo e do Padre Antonio Melo, pároco do município do Cabo e um dos tutores do sindicalismo rural pernambucano, que destacam as relações tensas que vinham mantendo desde que o sindicato optou por encaminhar as reivindicações dos trabalhadores do Cabo em um movimento de greve. Esse conflito pode ser compreendido através de questões sobre como a ação sindical poderia seguir daí em diante e quais os limites dessa ação, uma vez que a própria Justiça do Trabalho devolveu-a para os trabalhadores individuais ou por unidade de produção. Essa tensão vai se aprofundar até o quase rompimento de ambos em 1968, quando da última greve geral dos trabalhadores rurais do município, antes do endurecimento do regime militar em 1969, como se verá adiante.

A crise na agroindústria açucareira em Pernambuco se aprofunda nos anos seguintes, de 1967 e 1968. Por parte dos trabalhadores, aumentam consideravelmente a penúria, a miséria e o sofrimento social ${ }^{18}$ da categoria como um todo, seja pelo não pagamento dos salários atrasados e dos demais direitos trabalhistas, como férias, décimo terceiro salário e outras reivindicações, ${ }^{19}$ seja pelo aumento da pressão sobre os trabalhadores permanentes para expulsão dos engenhos e usinas,

${ }^{18}$ Para uma discussão sobre o conceito de sofrimento social, ver Koury (2007) e Dejours (2001).

${ }^{19}$ Embora constantes das reivindicações da greve de 1966 e regulamentadas pela justiça do trabalho de Pernambuco, não foram cumpridas pelo patronato até o final de 1967 . seja ainda pela contratação, em escala cada vez maior, de clandestinos em toda a mata pernambucana. Na cidade de Palmares, na região da mata sul de Pernambuco, o bispo local fez um memorando ao governo estadual e ao federal, alertandoos sobre o sofrimento e a miséria dos trabalhadores rurais da Zona da Mata e de Palmares em particular, dizendo que já estavam comendo ratos e invadindo armazéns da cidade em busca de comida. Relata também a decadência da cidade de Palmares e de outras que vivem exclusivamente das receitas pagas pelas usinas e pelos engenhos aos cofres públicos e dos salários dos trabalhadores rurais. Fala, enfim, da panela de pressão que se tornou a Zona da Mata como um todo e o município de Palmares, em particular, com a grave crise vivida na região.

O mesmo aconteceu com ofícios enviados ao governo estadual e ao governo federal pela Arquidiocese de Recife e Olinda e pela FETAPE sobre a situação vivida pelos trabalhadores rurais da região açucareira do estado. A FETAPE alertava os sindicatos sobre o perigo de infiltração subversiva no meio sindical, e enviou ofícios para o comando militar em Recife, relatando a presença de elementos estranhos que rondavam os sindicatos da mata pernambucana e o perigo que eles representavam para a paz social da região. ${ }^{20}$

A crise da agroindústria, o sofrimento desmedido dos trabalhadores rurais e a cultura do medo implantada e reforçada pela ditadura tornaram a Zona da Mata de Pernambuco, principalmente a mata sul, em 1967, um cenário de conflitos e tensões potencialmente explosivo. Tal situação motivou o General Costa e Silva, então no comando do governo militar brasileiro, a marcar uma viagem a Pernambuco e visitar a Zona da Mata, com especial interesse nas cidades de Palmares e do Cabo, onde se protagonizava a crise de forma mais aguda.

Nesse mesmo ano de 1967, a CONTAG (Confederação Nacional dos Trabalhadores na Agricultura) conseguiu retirar o interventor mantido no ${ }^{20}$ Notícias veiculadas no Diário de Pernambuco e no Jor-
nal do Comércio durante o ano de 1967. 
poder desde 1964, elegendo para a presidência da entidade José Francisco da Silva, pequeno proprietário do agreste pernambucano, com passagens pelo trabalho clandestino nos tempos de colheita e plantio da cana na Zona da Mata, segundo depoimento ao autor. José Francisco era um sindicalista formado nas hostes do SORPE. Começou sua militância como delegado sindical no município de Vicência, no Agreste pernambucano, em 1961, e atuou até 1967 como secretário geral da Federação em Pernambuco. Sua eleição para a presidência da CONTAG se afigura como um novo momento no processo de organização dos trabalhadores rurais brasileiros no pós-golpe e tem reflexos nos acontecimentos advindos da crise na mata pernambucana de 1967 e $1968 .{ }^{21}$

A visita de Costa e Silva a Pernambuco e às cidades de Palmares e do Cabo, na mata sul pernambucana, foi conturbada. O esquema de segurança em torno dele dificultava as manifestações públicas agendadas pelos sindicatos e pela igreja. Mesmo assim, foram realizadas reuniões intermediadas pela Secretaria do Trabalho e Ação Social do Governo do Estado, nas quais se apresentaram reivindicações e foi relatada a grave crise por que passavam os trabalhadores rurais na agroindústria açucareira local.

Várias lideranças sindicais da Zona da Mata e o presidente da FETAPE, com apoio de todos os bispos da região e do Arcebispo de Olinda e Recife, Dom Hélder Câmara, ${ }^{22}$ conseguiram entregar um documento a Costa e Silva com um relato da crise na Zona da Mata do estado e várias reivindicações dos trabalhadores rurais do estado como um todo. No rol de reivindicações se encontravam, entre outros itens: 1) necessidade de extensão da previdência social ao trabalhador rural; 2) orientação jurídica para questões trabalhistas ao trabalhador rural; 3) garantia do pagamento do salário mínimo integral; 4) proteção dos trabalhadores em relação

${ }^{21}$ Em sete eleicões sucessivas, José Francisco da Silva será reeleito presidente da CONTAG, onde permanece até 1989, e, entre 1990 a 1995, atuará na diretoria da entidade, sendo posteriormente alçado a assessor da Confederação.

${ }^{22}$ Com o apoio formal de vários sindicatos de trabalhadores urbanos e de várias entidades de intelectuais, artistas e estudantes de Pernambuco. à represália do patronato; 5) aplicação do Decreto $\mathrm{n}^{0} 57.020$, conhecido como Lei dos Dois Hectares de Terra; e, 6) a execução do Estatuto da Terra.

A visita de Costa e Silva a Pernambuco e às cidades citadas elevaram as expectativas dos trabalhadores e dos sindicalistas. Entretanto, as reuniões com sindicalistas e a entrega do documento sobre a Zona da Mata, com as reivindicações do movimento, subscrito pela Igreja Católica, geraram apenas promessas vagas de estudos para solução da crise na região.

Com o prolongamento e aprofundamento da crise, e sem qualquer manifestação do governo federal ou estadual, na ultima quinzena de dezembro de 1967, o sindicato rural do Cabo cedeu a pressões dos delegados sindicais e, em assembleia geral, decidiu por uma nova greve. Essa segunda greve cumpriu os ditames exigidos pela assembléia e teve início em 15 de janeiro de 1968.

A pauta de reivindicações, além dos mesmos itens presentes na greve anterior, até então não cumpridos (pagamento dos salários atrasados e férias de 1963 a 1967), incluía novos itens: jornada de oito horas de trabalho em substituição ao regime de tarefas $^{23}$ assinatura da carteira profissional de todos os trabalhadores permanentes e clandestinos contratados para o corte e plantio da cana e a reforma agrária. Os dois primeiros itens da pauta de reivindicação vão ser retomados pelo movimento sindical rural da mata pernambucana nas greves de 1979 e $1980,{ }^{24}$ que marcam a revitalização do

${ }^{23}$ Tarefa na mata pernambucana é a medida diária a ser cumprida por um trabalhador no corte da cana, estipulada em uma quantidade determinada de braças. Uma braca é equivalente a $2,3 \mathrm{~m}^{2}$ ou 0,26 toneladas. Um trabalhador rural, na Mata pernambucana, tem por tarefa o corte de oito toneladas por dia, o equivalente a pouco mais de 30 braças.

${ }^{24}$ A greve de 1979 foi a primeira greve após o endurecimento do regime militar em 1969, agora sob a liderança e coordenada pela FETAPE, com a paralisação de cerca de vinte mil trabalhadores canavieiros. No ano seguinte, 1980, uma nova greve deixa cerca de 250 mil trabalhadores da agroindústria açucareira de Pernambuco parados e dá início a uma série de greves bem sucedidas na época de dissídio na mata pernambucana. O movimento camponês reassume um papel reivindicativo e representacional em termos de classe trabalhadora no campo e, aqui, especificamente, na zona açucareira do estado. O movimento sindical na mata pernambucana atesta a sua singularidade e importância política no cenário de mobilização e organização dos trabalhadores rurais. Para uma análise no calor da hora das greves de 1979 e 1980, ver Sigaud $(1980 ; 1986)$ 
movimento rural no Brasil como um todo. O terceiro novo item, a reforma agrária, sempre foi colocado como um ponto importante na pauta de reivindicações do movimento camponês do estado e do Brasil como um todo. Na Zona da Mata, destacam-se, como elementos significativos, a questão dos dois hectares de terra, a manutenção dos sítios dos trabalhadores permanentes nas propriedades rurais e a desapropriação de engenhos como forma de pagamento dos salários e outros direitos trabalhistas atrasados.

Esse último item reaparece de forma evidente e com força na Mata pernambucana a partir dos anos de 1990, quando, junto com o MST (Movimento dos Trabalhadores Sem Terra), se inicia uma onda de ocupações de engenhos falidos e de terras ociosas na região (Sigaud, 2004). Naquele momento, tal item aparece como pauta das reivindicações permanentes do campesinato, mas associado diretamente aos dois hectares de terra, isto é, manutenção dos sítios de subsistência dos moradores e desapropriação para pagamento de atrasados.

Essa segunda greve do Cabo teve início à zero hora do dia 15 de janeiro de 1968, e cruzaram os braços os trabalhadores rurais de quinze engenhos. Após doze dias de paralisação, chegaram a um acordo nas juntas de conciliação e julgamento da Justiça do Trabalho. Nesse acordo, foi aceito o pagamento dos salários e dos demais direitos atrasados desde 1963; a troca de tarefa por horas de trabalho ficou de ser estudada, e a aplicação da Reforma Agrária a ser recomendada como uma medida de aplicação federal do Estatuto da Terra, por não ser da alçada da junta de conciliação do estado.

A FETAPE, mais uma vez, se colocou como contrária ao movimento, afirmando, em nota, que ele poderia prejudicar o "andamento dos compromissos assumidos” por Costa e Silva durante a sua visita a Pernambuco. Mostrou-se ainda preocupada com a tensão na região da Mata em seu todo, afirmando que a greve, no Cabo, "incentiva novos focos de greve" nos sindicatos da região.

A preocupação da Federação com a tensão na Zona da Mata fez com que ela marcasse reuniões sistemáticas com sindicalistas de outros mu- nicípios da região, com o intuito de desmobilizar os trabalhadores e "chamar à lucidez" os sindicatos rurais da região que queriam "seguir o exemplo do Cabo". ${ }^{25}$

Uma das consequências dessa segunda paralisação e do movimento de apoio de vários setores da igreja católica e de segmentos da sociedade civil pernambucana foi a aplicação, pela primeira vez desde a implantação do golpe, do Estatuto da Terra. Através do IBRA, foi desapropriada uma área de 3.326,24 hectares do engenho Tiriri, no município do Cabo, para a função de Reforma Agrária. Essa área deveria contemplar 320 famílias do município, compostas por moradores e ex-moradores do engenho desapropriado, como pagamento dos atrasados. Cada família receberia dez hectares. A decisão sobre as famílias que receberiam a terra, porém, ficaria sob a coordenação do Padre Antônio Melo, e não do sindicato rural do município.

Padre Antonio Melo, ao assumir o comando da distribuição das terras desapropriadas, descredenciou o sindicato de qualquer poder, mesmo que consultivo. Em reunião com as possíveis famílias a serem contempladas, transformou o projeto de distribuição em uma espécie de loteamento e criou a Cooperativa Agrícola do Tiriri. Os lotes do Padre Melo, como ficaram conhecidos na região, foram distribuídos aos lotistas (também denominação local), que receberam, em ato público festivo, os compromissos de compra e venda de cada lote. Parte do pagamento ficou condicionada aos atrasados e a outra parte seria paga diretamente ao Padre Antonio Melo anualmente, de acordo com o lucro da terra em regime de cooperativa, em um prazo de vinte anos. ${ }^{26}$

Esse fato desagradou a diretoria e, principalmente, o presidente do sindicato rural do Cabo. Considerado pela FETAPE como homem do Padre Antonio Melo, desde a primeira greve iniciou

${ }^{25}$ Jornal do Comércio, 19 jan. 1968.

${ }^{26}$ Em 1974, o autor entrevistou alguns lotistas do Padre Antonio Melo que informaram a desilusão com o assentamento e a dificuldade de pagarem o saldo devedor. Continuavam trabalhando nos engenhos e usinas da região, agora como trabalhadores clandestinos, e muitos repassaram os lotes para pessoas estranhas, por não terem condições de manutenção da terra (Koury, 1976). 
um relativo afastamento do controle do pároco, ampliando o dissenso a partir da segunda greve e, principalmente, pela forma como os lotes de terra foram distribuídos.

O presidente do sindicato rural do município se manifestou, em entrevista ao Diário de Pernambuco do dia 21 de janeiro de 1968, satisfeito com o final pacífico do movimento, embora ameaçasse o patronato com uma nova greve, caso não fosse cumprido o acordo realizado com o aval da Delegacia Regional do Trabalho. Declarou, nessa mesma entrevista, o seu descontentamento com os rumos da distribuição das terras desapropriadas sob a supervisão e o comando do Padre Antonio Melo.

Passados sete meses do dissídio, a não-observância do acordo realizado na última greve do Cabo fez com que pairasse no ar um clima de tensão e, no dia 15 de agosto de 1968, em assembleia geral, foi decretada nova greve no município. Essa terceira greve, além das reivindicações anteriores, acrescentou mais um item: o ingresso dos trabalhadores rurais no quadro de contribuintes do INPS (Instituto Nacional de Previdência Social). A nova greve foi marcada para ter início à zero hora do dia 03 de setembro de 1968 e atingia todos os engenhos e usinas do município.

A FETAPE, de início, se colocou contra o movimento, afirmando ao Diário de Pernambuco do dia 16 de agosto de 1968 que, "no fim da história, nada se resolve em benefício dos trabalhadores, mas do patrão". A Delegacia Regional do Trabalho, por sua vez, apelou para "o patriotismo dos empregadores e empregados", ${ }^{27}$ para que chegassem a um acordo sem precisar de uma nova greve no município.

O medo da Federação e dos delegados do trabalho era de que, caso houvesse a deflagração do movimento grevista no Cabo, ele poderia expandir-se para toda a Zona da Mata do estado, atingindo mesmo os canaviais do vizinho estado de Alagoas, face à semelhança das reivindicações, das queixas e do sofrimento social dos trabalhadores na agroindústria açucareira.

${ }^{27}$ Jornal do Comércio, de 17 ago. 1968.
A FETAPE enviou um documento ao ministro do trabalho que - envolvido recentemente com as repercussões das greves de Contagem (Minas Gerais) e Osasco (São Paulo) nos meses de abril e junho de 1968, da greve dos bancários em Minas Gerais entre os meses de julho e agosto e do crescimento e radicalização do movimento estudantil em todo o país - encaminhou um memorando à Delegacia Regional do Trabalho em Pernambuco solicitando que se envidassem todos os esforços para a solução da crise no Cabo.

A Delegacia Regional do Trabalho fez uma série de reuniões com a diretoria do sindicato. Entretanto, sem dar qualquer garantia de que as reivindicações seriam cumpridas pelo patronato, ficou à mercê da intransigência patronal e da pressão dos trabalhadores para que o sindicato desse prosseguimento à greve. Em uma declaração à imprensa, o delegado do trabalho chamou o presidente do sindicato rural do Cabo de intransigen$\mathrm{te}^{28} \mathrm{e}$, em uma assembleia tumultuada na sede do sindicato, afirmou a ilegalidade do movimento e a falta de clareza e a generalidade da pauta de reivindicações. Afirmou, ainda, que interviria no sindicato caso ele insistisse em levar adiante o movimento de greve.

O sindicato rural do Cabo entrou com uma ação no Tribunal Regional do Trabalho para garantir a legalidade do movimento e enviou um relatório ao Ministério do Trabalho afirmando a legalidade da greve e caracterizando a ação do delegado regional do trabalho de coação. Nos termos do relatório,

... [a Delegacia Regional do Trabalho] pretende impedir a livre manifestação do pensamento dos trabalhadores rurais do Cabo, frustrando-os naquilo que mais direito possuem que é de lutar com todas as armas, para receber salários atrasados, para cujo ganho trabalham intensamente. (Diário de Pernambuco, 19 set. 1968)

O ministro do trabalho enviou a Pernambuco o diretor geral da Delegacia Nacional do Trabalho para observar o andamento dos acontecimentos no

${ }^{28}$ Jornal do Comércio, de 23 ago.1968. 
município do Cabo, no mesmo momento que o Tribunal Regional do Trabalho julgava o processo encaminhado pelo sindicato rural do município, e afirmou que o delegado regional do trabalho "não tem competência para julgar sobre legalidade ou não deste e de qualquer outro movimento de greve", ${ }^{29}$

Ao chegar a Pernambuco, o diretor geral da Delegacia Nacional do Trabalho seguiu para o município do Cabo e, em vez de procurar diretamente o presidente do sindicato, foi à casa da paróquia e teve uma demorada reunião com o Padre Antonio Melo e com o delegado regional do trabalho. Depois dessa longa reunião, seguiu para o sindicato e solicitou à diretoria um adiamento de quinze dias na deflagração do movimento, para que o Ministério do Trabalho pudesse achar uma saída para a crise local. O presidente e toda a diretoria do sindicato recusaram a proposta e avisaram que, logo após a publicação do anuncio da legalidade do movimento pelo Tribunal Regional do Trabalho, entrariam em greve.

A recusa do sindicato em atender ao pedido do diretor geral da Delegacia Nacional do Trabalho desagradou o Padre Antonio Melo. As relações já tensas entre o presidente do sindicato e o padre tornaram-se mais delicadas, beirando uma ruptura.

A sociedade civil encontrava-se mobilizada no apoio aos trabalhadores rurais do município. A FETAPE, por sua vez, assessorada pela CONTAG, reviu suas posições contrárias ao movimento, solidarizou-se com o sindicato e os trabalhadores rurais do Cabo, colocando-se à sua disposição e permanecendo como uma observadora atenta, mas de fora do movimento.

No dia 01 de outubro de 1968, o próprio ministro do trabalho chegou à cidade do Recife e seguiu diretamente para o sindicato rural do Cabo. No encontro com o presidente do sindicato, apelou para o seu patriotismo, solicitando que pusesse um ponto final no processo de greve e deixasse nas mãos das autoridades as soluções para a grave crise local. Não conseguiu demover o processo de greve, mas obteve um adiamento do o início do

${ }^{29}$ Jornal do Comércio, 20 set. 1968. movimento, agora com início previsto para a zero hora do dia 07 de outubro de 1968.

A greve, enfim, teve início no dia 07 de outubro e, nos seus cinco dias de duração, recebeu apoio e solidariedade de vários segmentos da sociedade civil de Pernambuco e do Brasil. A FETAPE e a CONTAG se colocaram à disposição do movimento, mas ficaram como observadoras atentas, não se envolvendo diretamente com a greve. Os sindicatos rurais da mata pernambucana enviaram moções de solidariedade. O Arcebispo de Olinda e Recife, Dom Hélder Câmara, foi in loco manifestar sua solidariedade ao movimento, acompanhado de representantes do Movimento de Justiça e Paz, da Ordem dos Advogados e do Conselho de Medicina. O SORPE, na figura do Padre Paulo Crespo, também se solidarizou com o movimento.

Na cidade do Recife, no dia 09 de outubro de 1968, os estudantes secundaristas e universitários saíram pelas ruas da cidade proclamando solidariedade ao movimento e arrecadando alimentos e dinheiro para apoiá-lo. Às dezessete horas, reuniram-se no prédio da antiga Faculdade de Filosofia da Universidade Federal de Pernambuco, conhecida como Fafipinha, na Rua Nunes Machado, centro estendido do Recife, para avaliação da arrecadação e da continuidade das ações de solidariedade e apoio à greve do Cabo. Às dezenove horas, a pedido da direção da Fafipinha, a polícia invadiu o prédio e expulsou com cassetetes e bombas de efeito moral os estudantes lá reunidos. As aulas foram encerradas e a faculdade fechada até o dia seguinte.

Delegações estudantis se dirigiram para a sede do sindicato do Cabo, com o valor arrecadado em dinheiro e mantimentos, onde prestaram homenagem aos trabalhadores e relataram os acontecimentos recentes ao presidente do sindicato e ao comando de greve local. Por seu turno, o ministro do trabalho afirmou à imprensa local e nacional que só sairia de Pernambuco quando resolvesse o impasse causado pela greve no Cabo.

Desde a recusa do presidente do sindicato rural de ceder à pressão para adiamento do movimento, o ministro do trabalho se recusava a falar 
diretamente com ele, colocando a delegacia regional do trabalho ou o Padre Antonio Melo como intermediários de suas ações. No dia 10 de outubro, marcou um encontro com o presidente e um porta-voz do comando de greve. Mas, ao chegar ao Cabo, disse que, antes de conversar com o sindicato, precisava do aconselhamento do pároco local. Após a conversa com o padre, marcou, por fim, uma reunião com o sindicato, na qual se encontravam presentes toda a diretoria e todos os membros do Comando de Greve ${ }^{30}$ Nessa reunião, advertiu o sindicato e, diretamente, o seu presidente, de que não toleraria desvirtuamento da verdade, insinuando atos de corrupção da diretoria e acusando o seu presidente de coação moral dos trabalhadores para fins pessoais. ${ }^{31}$

No dia seguinte, 11 de outubro, o ministro do trabalho anunciou, em rede nacional, algumas medidas contidas na pauta de reivindicações dos grevistas do Cabo. As reivindicações aceitas pelo ministro do trabalho foram: 1) inscrição imediata dos trabalhadores rurais do Cabo no INPS; 2) designação de uma comissão paritária para revisão das tarefas no campo, fixando um limite de oito horas de trabalho diárias; 3) instalação de unidades médicas do INPS no Cabo, dentro de um prazo de oito dias; e 4) intervenção imediata do Ministério do Trabalho na Cooperativa Agrícola do Tiriri.

Relato de uma entrevista com um membro do Comando de Greve ao autor. O entrevistado era, na época, militante da AP (Ação Popular), com atuação entre os trabalhadores rurais do município do Cabo, chegando a participar das duas últimas greves do município e do Comando de Greve da greve geral do município em outubro de 1968. Foi preso no ano seguinte, junto com outro militante da organização. Estiveram envolvidos também militantes de outras organizações políticas de esquerda como o PC do B (Partido Comunista do Brasil), PCBR (Partido Comunista Brasileiro Revolucionário) e outros.

${ }^{31}$ Diário de Pernambuco, 11 out. 1968. mento unificado. E deu um parecer em que acusava o sindicato rural do Cabo de procedimento abusivo frente às condições e limites contidos na Lei de Greve, dividindo a busca de recebimento dos salários atrasados por unidade de produção.

Nesse parecer, alega ainda que as reivindicações sobre a reforma agrária, a aplicação do Estatuto da Terra e o direito à previdência social eram motivadas por razões políticas e não econômicas, acusando mais uma vez o sindicato de abusar do seu poder de manipulação junto à base. Encerrou o parecer, por fim, considerando a greve geral do Cabo ilegal, política e abusiva, não condizente com os novos tempos. ${ }^{32} \mathrm{O}$ parecer termina com a sugestão de uma intervenção no sindicato.

\section{CONCLUSÃO}

Este artigo buscou passar em revista os anos posteriores ao golpe militar de 1964, focalizando sua atenção no processo de reorganização do movimento sindical rural em Pernambuco e, particularmente, na mata pernambucana. As dificuldades acarretadas pelo golpe militar ao campesinato, em termos de repressão à reivindicação e à defesa de direitos trabalhistas, a fase assistencial da estrutura sindical, o controle político sindical pelo clero conservador, as dificuldades com o patronato local, as crises sucessivas da agroindústria no estado e os primeiros dissensos com o Estado autoritário servem como pano de fundo para a compreensão dos acontecimentos aqui analisados, que tiveram expressão em três processos de greve no município do Cabo com repercussão em toda a região e no movimento sindical brasileiro.

Em 13 de dezembro de 1968, foi promulgado o Ato Institucional $n^{\circ} 5$, que consolidou o Estado autoritário no país, concentrando poderes excepcionais, cuja fase mais violenta e repressiva estendeu-se até 1974. Nesse período, o sindicalismo rural aprofundou a sua face assistencialista, com a ampliação da rede sindical ${ }^{32}$ Diário de Pernambuco, 26 nov. 1968. 
por todo Pernambuco e pelo Brasil. A Mata pernambucana acelerou ainda mais a extrusão da mão de obra permanente, e a agroindústria açucareira contratou, cada vez mais, mão de obra clandestina, expulsando os seus moradores. Na região Agreste do estado, também se aprofundou o processo de expulsão de pequenos proprietários rurais, para dar lugar à pecuária extensiva, o que aumentou as hordas de excluídos e desempregados, aglutinados em bairros-dormitório nas periferias das cidades da Zona da Mata ou vagando pelo Brasil afora como trabalhadores temporários.

A previdência social rural, item contemplado a partir da greve geral de outubro de 1968 do Cabo, foi iniciada, como prometido, porém revertida como mais uma arma de controle dos trabalhadores rurais e da passividade da estrutura sindical rural. Após ter sido criada, sua execução ficou a cargo da estrutura sindical rural, o que tornou os sindicatos meros agentes assistenciais do Estado, com suas ações dependentes quase exclusivamente desse serviço (Koury, 1981). Esse fato ampliaria a fase assistencial dos sindicatos rurais, e vincularia seus serviços aos associados, difundindo-se a ideia de que os sindicatos rurais são dos associados e não de todos os trabalhadores rurais. ${ }^{33}$

Os anos de chumbo têm início.

(Recebido para publicação em outubro de 2008)

(Aceito em janeiro de 2009)
IPES. Instituto de Pesquisas e Estudos Sociais. Reforma agrária: problemas, base e soluções. Rio de Janeiro: Ediçõ̃es do IPES, 1964

KOURY, Mauro Guilherme Pinheiro. Breve história do movimento camponês no Nordeste. Raízes, Campina Grande, PB, v. 2 n. 2/3, p. 167-176, jan./dez. 1983.

Sofrimento social. Movimentos sociais na Paraíba através da imprensa, 1964 a 1980. João Pessoa: Ed. Universitária, 2007.

NEVES, Mozart Borba. Uma experiência com o Boia Fria. Ensaios de Opinião - A Questão Agrária, Rio de Janeiro, v. 11, Paz e Terra, 1979. p. 63-68.

ROSA, Marcelo Carvalho. As novas faces do sindicalismo rural brasileiro: a reforma agrária e as lutas sindicais na Zona da Mata de Pernambuco. In: LEVY, Bettina; GIANETELLI, Natalia (Org.). Movimientos sociales y nuevos conflictos en América Latina y el Caribe. Buenos Aires: CLACSO, 2006. p. 349-378.

SIGAUD, Lygia, Os clandestinos e os direitos. Estudo sobre os trabalhadores da Cana de Açúcar em Pernambuco. São Paulo, Duas Cidades, 1979. $\overline{1980 .}$

Greve nos engenhos. Rio de Janeiro: Paz e Terra,

A luta de classes em dois atos: notas sobre um ciclo de greves camponesas. Dados: revista Brasileira de Ciências Sociais, Rio de Janeiro, IUPERJ, v. 29, n. 3 p.319334, 1986.

Ir à Justiça: os direitos entre trabalhadores rurais. In: NOVAES, Regina (Org.) Direitos humanos. Temas e perspectivas. Rio de Janeiro: ABA/Mauad/Fundação Ford, 2001. v. 1. p. $50-72$

Ocupações de terra, Estado e Movimentos Sociais no Brasil. Cuadernos de Antropología Social. n. 20, p. 11-23, 2004.

SILVA, José Gomes Da. A reforma agrária: frustração camponesa ou instrumento de desenvolvimento? Rio de Janeiro, Zahar, 1971.

TAMER, Alberto. O mesmo Nordeste. São Paulo, Herder, 1968

\section{REFERÊNCIAS}

CASTELO BRANCO, Marechal Humberto de Alencar. Discurso no Ministério da Fazenda. In: A REVOLUÇÃO de 31 de março $-2^{\circ}$ aniversário: colaboracão do Exército. Rio de Janeiro: Biblioteca do Exército Editora, 1966. p. 245272 ,

DEJOURS, Christophe. A banalização da injustiça social. 4.ed. Rio de Janeiro: Ed. FGV, 2001.

IBAD. Instituto Brasileiro de Ação Democrática. Recomendações sobre a reforma agrária. Rio de Janeiro: Edições do IBAD, 1961.

\footnotetext{
${ }^{33}$ Fato que se tornará um dos pontos importantes discutidos e modificados na retomada do processo de mobilização dos sindicatos rurais a partir de 1974 . Ver Neves (1979).
} 


\section{RURAL STRIKES IN THE BRAZILIAN ZONA DA MATA: Pernambuco, 1964 and 1968}

\section{Mauro Guilherme Pinheiro Koury}

This paper reviews the rural strikes in the sugar agribusiness sector of Zona da Mata in Pernambuco, Brazil, in the period post- military coup, from 1964 to 1968, based in documental material, especially newspaper articles of the time. Observing the composition of the block in power and the alliances established between conservative political sectors and the clergy, the paper explores the ambiguity of the role of the rural unions of the area, at the time, a role that oscillates between an organ of cooperation with the authoritarian State and of representation of the interests of the rural workers' of the area post- 64 .

KEYwORDS: rural strikes, authoritarianism, reorganization of the rural syndical movement.

\section{CYCLE DE GREVES DANS L'AGROINDUSTRIE SUCRIERE: Pernambuco, 1964 et 1968}

\section{Mauro Guilherme Pinheiro Koury}

Sur la base de documents essentiellement issus de journaux de l'époque, cet article présente une nouvelle lecture des grèves dans le secteur de l'agroindustrie du sucre de la région de "Zona da Mata" dans l'Etat de Pernambouco au Brésil, au cours de la période allant de 1964 à 1968, après le coup d'état militaire. En observant la composition des forces du pouvoir et des alliances existantes entre les secteurs politiques conservateurs et le clergé, l'article se penche sur l'ambiguïté du rôle des syndicats ruraux de la région à ce moment-là, qui oscille entre un organe de collaboration avec l'Etat autoritaire et de représentation des intérêts de la classe des travailleurs ruraux de la région après 1964.

MOTS-CLÉs: grèves rurales, autoritarisme, restructuration du mouvement syndical rural.

Mauro Guilherme Pinheiro Koury - Professor do Departamento de Ciências Sociais da UFPB. Doutorando de Sociologia da UFSCar. Coordenador do GREM - Grupo de Pesquisa em Antropologia e Sociologia das Emoções da mesma universidade. Desenvolve atualmente pesquisas na área de Sociologia e Antropologia das Emoções com ênfase em medos urbanos e construção das cidades, e Sociologia Rural, com ênfase em sindicalismo rural. Publicou, entre outros: Sociologia da Emoção. O Brasil urbano sob a ótica do luto (Petrópolis, Editora Vozes, 2003), Sofrimento Social (João Pessoa, Editora Universitária, 2007), De que João Pessoa tem Medo? Uma abordagem em Antropologia das Emoções (João Pessoa, Editora Universitária, 2008) e Emoções, Sociedade e Cultura (Curitiba, Editora ÇRV, 2009). 